\title{
MINIMALLY INVASIVE PLATE OSTEOSYNTHESIS IN METAPHYSEAL FRACTURE OF TIBIA AND FEMUR
}

\author{
Sagar Tomar1, Gyaneshwar Tonk², Nitesh Rustagi3 ${ }^{3}$,Amit Gupta4, Gaurav Menwal5
}

${ }^{1}$ Senior Resident, Department of Orthopaedics, IGESI Hospital, Delhi.

${ }^{2}$ HOD, Department of Orthopaedics, LLRM Medical College, Meerut.

${ }^{3}$ Senior Resident, Department of Orthopaedics, LLRM Medical College, Meerut.

${ }^{4}$ Lecturer, Department of Orthopaedics, LLRM Medical College, Meerut.

${ }^{5}$ Senior Resident, Department of Orthopaedics, LLRM Medical College, Meerut.

\section{ABSTRACT}

\section{BACKGROUND}

Metaphyseal fractures of long bones of lower limb are difficult to manage. In our study, we have evaluated the radiological and functional outcome of minimally invasive plate osteosynthesis (MIPO) technique for metaphyseal fracture of femur and tibia.

\section{MATERIALS AND METHODS}

A total of 37 metaphyseal fractures of long bone of lower limb were included in the study. The fractures were treated with minimal incisions, both at proximal and distal ends of plate. The anatomical metaphyseal locking plate was then inserted subperiosteally and the fracture was bridged after which the plate was fixed. The patients were followed up and the progresses were evaluated at regular interval by Johner-Wruhs' criterion and lower extremity functional score.

\section{RESULTS}

All the fractures united well. The mean time of union of distal femur, proximal and distal tibia are 18 (range 14 - 24), 18 (range 14 22) and 17 (range 16 - 24) weeks respectively. The mean range of motion at knee of fracture around knee was $105^{\circ}$, while for fracture at ankle the range of motion was a mean dorsiflexion of $19^{\circ}$ and mean $30^{\circ}$ plantar flexion. According to Johner-Wruhs criterion results were excellent in 14, good in 17, fair in 5 and poor in 1 patient. By LEFS system, 34 patients have no difficulty in doing their work, while only 3 patients have a little bit of difficulty. No patients required bone grafting. The complication rates were also low.

\section{CONCLUSION}

For metaphyseal fractures, MIPO can be regarded as an optimal treatment modality which achieves good bone union and functional results with minimum soft tissue damage.

\section{KEYWORDS}

Metaphysis, Fracture, Minimally Invasive Surgery, Bone Grafting.

HOW TO CITE THIS ARTICLE: Tomar S, Tonk G, Rustagi N, et al. Minimally invasive plate osteosynthesis in metaphyseal fracture of tibia and femur. J. Evolution Med. Dent. Sci. 2017;6(15):1204-1208, DOI: 10.14260/Jemds/2017/262

\section{BACKGROUND}

Metaphyseal fractures of long bones of lower limb are difficult to manage. Earlier, when the treatment was done using intramedullary osteosynthesis it does not provide stable rigid fixation, while when open reduction and internal fixation is attempted with classical plates it requires a quite larger incision causing larger periosteal damage. ${ }^{1}$ Furthermore, the fracture were previously subjected to anatomical reduction and stabilisation, which lead to superior biomechanical results, but the long-term biological effects were diminished.2

Because of these drawbacks, research and development leads to the invention of new plates called "biological plate" and new surgical procedures, one of which is "minimally invasive plate osteosynthesis" (MIPO). Biological bridge plating uses the plate as an extramedullary splint fixed to the

Financial or Other, Competing Interest: None.

Submission 25-03-2015, Peer Review 26-03-2015,

Acceptance 06-05-2015, Published 20-02-2017.

Corresponding Author:

Dr. Sagar Tomar,

\#D/GE 271 Green Estate,

Modipuram, Meerut, India.

E-mail: sagar2n@gmail.com

DOI: $10.14260 /$ jemds $/ 2017 / 262$

(c) (i) $(-)$ two main fragments. The complex fracture zone is not opened directly; however, it is bridged by the plate. Length, alignment and rotation are restored, but anatomical reduction of each fragment is not attempted. ${ }^{3}$

In our study, we have evaluated radiological and functional outcomes of MIPO for metaphyseal fracture of distal femur and tibia.

\section{MATERIALS AND METHODS}

This study was conducted in the Department of Orthopaedics of L. L. R. M Medical College, Meerut. A total of 37 patients with metaphyseal fracture of distal femur and tibia were included in the study in period of 2013 - 2014. All these patients were then treated with MIPO method of plating.

The inclusion criterion of our study included all the metaphyseal fracture of femur and tibia of age more than 15 years and open fractures Grade I and Grade II (GustiloAnderson).

The exclusion criterion included the pathological fractures, Open fracture Gustilo-Anderson Grade III, associated vascular injury, the presence of any co-morbid illness.

All the patients received primary treatment in the form of IV fluids and splintage in the form of plaster slab or skeletal traction wherever indicated and thorough clinical 
examination was done to rule out associated injury. All these patients were examined radiologically with standard anteroposterior and lateral views.

A day before the planned surgery, the patient was subjected to pre-anaesthetic checkup to obtain the fitness status for surgery and the part of the patient was prepared.

The preoperative plan includes the number, type, location and order of insertion of the screws. Contouring of the plate if necessary was also carried out preoperatively. The surgery was carried out under regional anaesthesia and tourniquet was used. The patient was made to lie supine on the radiolucent table. The approaches used for different fractures were Distal femur: lateral approach, Proximal tibia: lateral approach, Distal tibia: medial or anterolateral approach. Skin incisions were made corresponding to position of both ends of the plate.

The submuscular tunnel was then prepared with the tunnelling instrument or blunt dissection over the periosteum except in the MIPO of the medial surface of the distal tibia, in which the subcutaneous tunnel was prepared over the periosteum. After this plate was inserted and positioned and reduction was achieved by indirect reduction technique and with the help image intensifier the length, axis and rotation of the limb were checked under the image intensifier and this was followed by plate fixation with the screws.

Post-operatively, physiotherapy was started as soon the pain subsided with active and assisted range of motion exercise. In our study, we have used pre-contoured titanium LCP or stainless steel LCP as according to the affordability of the patient.

The patients have assessed during the follow-ups in the form of bone union rate, deformity, limb length discrepancy, range of motion of joint, full weight bearing, return to preinjury status, Complication - infection, implant failure, malunion, non-union. The information gathered were noted in model case sheet at the follow-up period each at 3 weeks, 6 weeks, 3 months, 6 months and also in between these period based on previous assessment of patient on follow-ups.

The clinical and functional results were evaluated with the help of lower extremity functional scoring system ${ }^{4}$ and Johner-Wruhs's criterion (Annexure).

\section{RESULTS}

A total of 37 patients were analysed in this study. The age varied from 17 to 65 years with the mean age of patient among males 40 years (SD - 3.18) and among female 43 years (SD - 2.98) (P value - .0001). Most patients were from the $3^{\text {rd }}$ and $4^{\text {th }}$ decade. The fracture was more common in males (86\%). Right side was more commonly involved (59\%). RTA was the most common mode of injury (76\%).

\begin{tabular}{|c|c|c|}
\hline Age Group & No. of Patient & Percent \\
\hline$>16-25$ & 1 & $2.70 \%$ \\
\hline$>26-35$ & 13 & $35.14 \%$ \\
\hline$>36-45$ & 15 & $40.54 \%$ \\
\hline$>46-55$ & 6 & $16.22 \%$ \\
\hline$>55$ & 2 & $5.41 \%$ \\
\hline Total & $\mathbf{3 7}$ & $\mathbf{1 0 0 . 0 0 \%}$ \\
\hline \multicolumn{3}{|c}{ Table 1 } \\
\hline
\end{tabular}

There were 14 fractures of distal femur, 16 fractures of proximal tibia, 7 fractures of distal tibia. Twenty four of the fractures were extra-articular; twelve of the fractures were intra-articular. There were 7 patients with Grade I compounding, 2 patients with Grade II compounding (Gustilo-Anderson).

The patients were examined and were allowed weight bearing. The mean time of partial weight bearing in fractures of distal femur, proximal tibia and distal tibia is about 10.14 weeks (SD - 2.14); 9.71 weeks (SD - 1.38); 9.37 weeks (SD - 1.74). The mean time of partial weight bearing in fractures of distal femur, proximal tibia and distal tibia is about 16 weeks (SD - 3.23); 15.28 weeks (SD - 2.75); 15.31 weeks (SD - 2.70).

Most of the patients achieved near normal range of motion of near joint. The surgery around knee has an average range of motion of $106^{\circ}$ (Range $0^{\circ}-140^{\circ}$ ), seven patients have an extension lag of about $10^{\circ}$. The surgery around ankle have an average of $19^{\circ}$ dorsiflexion and $30^{\circ}$ of plantar flexion.

All the 37 fractures healed well and the mean time of bone union in fractures of distal femur, proximal tibia and distal tibia is about 18.14 weeks (Range 14 - 24; SD - 3.08); 18.57 weeks (Range 14 - 22; SD - 2.76); 17.12 weeks (Range 16 - 24; SD - 2.41). However, bone healing depends on age, activity, general condition, fracture geometry and soft tissue condition.

\begin{tabular}{|c|c|c|c|c|c|c|c|c|}
\hline \multirow{2}{*}{ Fracture } & \multirow{2}{*}{$\begin{array}{l}\text { Mean Weight } \\
\text { Bearing Time }\end{array}$} & \multirow{2}{*}{$\begin{array}{c}\text { Complete Weight } \\
\text { Bearing }\end{array}$} & \multirow{2}{*}{$\begin{array}{l}\text { Union Time } \\
\text { (Weeks) }\end{array}$} & \multirow{2}{*}{$\begin{array}{c}\text { Union Range } \\
\text { (Weeks) }\end{array}$} & \multicolumn{4}{|c|}{ Functional Scoring } \\
\hline & & & & & Excellent & Good & Fair & Poor \\
\hline Distal Femur & 10.14 & 16 & 18.14 & $14-24$ & 5 & 7 & 1 & 1 \\
\hline Proximal Tibia & 9.71 & 15.28 & 18.57 & $14-22$ & 6 & 7 & 3 & 0 \\
\hline Distal Tibia & 9.37 & 15.31 & 17.12 & $16-24$ & 3 & 3 & 1 & 0 \\
\hline Total & & & & & 14 & 17 & 5 & 1 \\
\hline
\end{tabular}

The overall functional outcomes of our study evaluated by Johner-Wruhs' criterion are: Excellent in 14 (38\%), Good in $17(46 \%)$, Fair in $5(13 \%)$ and Poor in 1 patient. While evaluating the results by lower extremity functional scoring system 34 out of 37 patients have no difficulty in doing their daily activities, while 3 out of 37 patients have a little bit of difficulty. The average maximum functional score was $84 \%$.

The results in the two criterions are confounding, because both the criterion assesses different aspects of functional outcome. The LEFS assess the subjective function which has individual variability, while Johner-Wruhs' criterion assess the clinical and functional outcome. In our study, there was only three cases of infection (8.1\%), which was at the distal tibia fracture. This probably was because of the poor blood supply and soft tissue coverage at distal tibia.

Five patients were having pain, which were of mild intensity and were not hampering their daily routine activities. There was no case of implant breakage or failure. 
The overall significant complication could be summarised as: Pain - 5 (16.1\%), Infection - $3(8.1 \%)$, Varus/valgus deformity $\left(>10^{\circ}\right)-1(3.2 \%)$, Delayed union $-2(5.4 \%)$, Shortening/lengthening $(>1 \mathrm{~cm})-0$.

\section{Illustration Cases}

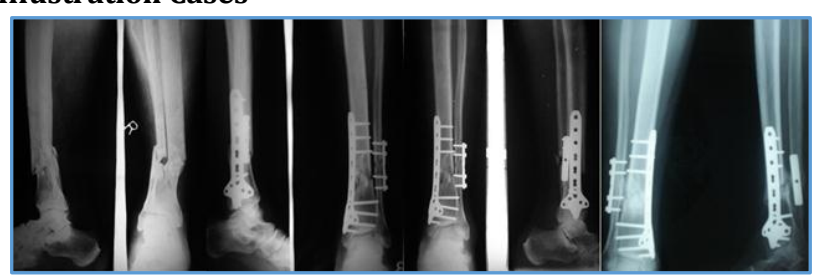

Distal Tibia Fracture: 43 A3 Union at 16 Weeks
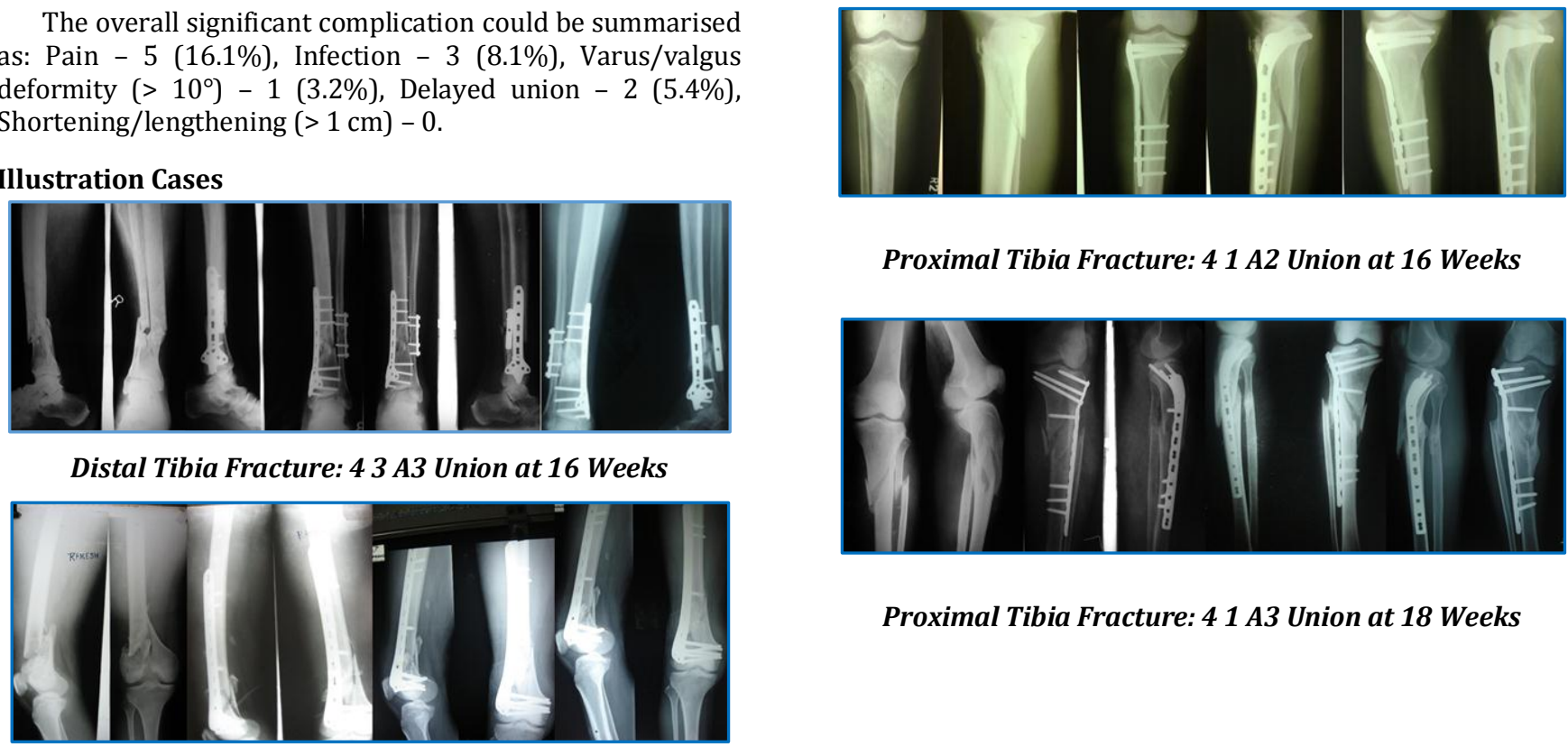

Proximal Tibia Fracture: 41 A2 Union at 16 Weeks

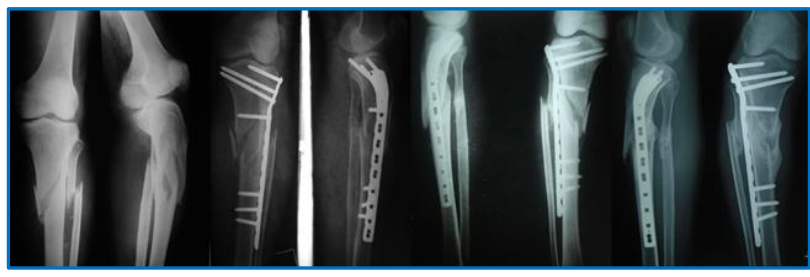

Proximal Tibia Fracture: 41 A3 Union at 18 Weeks

Distal Femur Fracture: 33 C2 Union at 18 Weeks

\begin{tabular}{|c|c|c|c|c|c|}
\hline Activities & $\begin{array}{c}\text { Extreme Difficulty or } \\
\text { Unable to Perform } \\
\text { Activity }\end{array}$ & $\begin{array}{c}\text { Quite a } \\
\text { Bit of } \\
\text { Difficulty }\end{array}$ & $\begin{array}{l}\text { Moderate } \\
\text { Difficulty }\end{array}$ & $\begin{array}{c}\text { A Little } \\
\text { Bit of } \\
\text { Difficulty }\end{array}$ & $\begin{array}{c}\text { No } \\
\text { Difficulty }\end{array}$ \\
\hline $\begin{array}{l}\text { 1. Any of your Usual Work, Housework } \\
\text { or School Activities }\end{array}$ & 0 & 1 & 2 & 3 & 4 \\
\hline $\begin{array}{ll}2 . & \text { Your Usual Hobbies, Recreational } \\
& \text { or Sporting Activities }\end{array}$ & 0 & 1 & 2 & 3 & 4 \\
\hline 3. $\quad$ Getting Into or Out of the Bath & 0 & 1 & 2 & 3 & 4 \\
\hline 4. $\quad$ Walking between Rooms & 0 & 1 & 2 & 3 & 4 \\
\hline 5. Putting on your Shoes or Socks & 0 & 1 & 2 & 3 & 4 \\
\hline 6. $\quad$ Squatting & 0 & 1 & 2 & 3 & 4 \\
\hline $\begin{array}{l}\text { 7. Lifting an object like a Bag of } \\
\text { Groceries from the Floor }\end{array}$ & 0 & 1 & 2 & 3 & 4 \\
\hline $\begin{array}{ll}\text { 8. } & \text { Performing Light Activities } \\
\text { Around your Home }\end{array}$ & 0 & 1 & 2 & 3 & 4 \\
\hline $\begin{array}{l}\text { 9. Performing Heavy Activities Around } \\
\text { your Home }\end{array}$ & 0 & 1 & 2 & 3 & 4 \\
\hline 10. Getting Into or Out of a Car & 0 & 1 & 2 & 3 & 4 \\
\hline 11. Walking 2 Blocks & 0 & 1 & 2 & 3 & 4 \\
\hline 12. Walking a Mile & 0 & 1 & 2 & 3 & 4 \\
\hline $\begin{array}{l}\text { 13. Going Up or Down } 10 \text { Stairs } \\
\text { (About } 1 \text { Flight of Stairs) }\end{array}$ & 0 & 1 & 2 & 3 & 4 \\
\hline 14. Standing for 1 Hour & 0 & 1 & 2 & 3 & 4 \\
\hline 15. Sitting for 1 Hour & 0 & 1 & 2 & 3 & 4 \\
\hline 16. Running on Even Ground & 0 & 1 & 2 & 3 & 4 \\
\hline 17. Running on Uneven Ground & 0 & 1 & 2 & 3 & 4 \\
\hline $\begin{array}{l}\text { 18. Making Sharp Turns } \\
\text { while Running Fast }\end{array}$ & 0 & 1 & 2 & 3 & 4 \\
\hline 19. Hopping & 0 & 1 & 2 & 3 & 4 \\
\hline 20. Rolling Over in Bed & 0 & 1 & 2 & 3 & 4 \\
\hline Column Totals & $\mathbf{0}$ & 1 & 2 & 3 & 4 \\
\hline
\end{tabular}




\begin{tabular}{|c|c|c|c|c|}
\hline & $\begin{array}{c}\text { Excellent } \\
\text { (Left to Right) }\end{array}$ & Good & Fair & Poor \\
\hline $\begin{array}{c}\text { Non-Union, Osteomyelitis, } \\
\text { Amputation }\end{array}$ & None & None & None & Yes \\
\hline $\begin{array}{c}\text { Neurovascular } \\
\text { Disturbances }\end{array}$ & None & Minimal & Moderate & Severe \\
\hline $\begin{array}{c}\text { Deformity } \\
\text { Varus/Valgus, } \underline{\mathrm{o}} \\
\text { Anteversion/Recurvation, } \underline{\mathrm{o}} \\
\text { Rotation, } \underline{\mathrm{o}} \\
\text { Shortening, } \mathrm{mm}\end{array}$ & $\begin{array}{l}\text { None } \\
0-5 \\
0-5 \\
0-5\end{array}$ & $\begin{array}{l}2-5 \\
6-10 \\
6-10 \\
6-10\end{array}$ & $\begin{array}{c}6-10 \\
11-20 \\
11-20 \\
11-20\end{array}$ & $\begin{array}{l}>10 \\
>20 \\
>20 \\
>20\end{array}$ \\
\hline $\begin{array}{c}\text { Mobility, \% } \\
\text { Knee Normal } \\
\text { Ankle Normal } \\
\text { Subtalar Joint }\end{array}$ & $\begin{array}{l}\text { Normal } \\
\text { Normal } \\
\text { Normal }\end{array}$ & $\begin{array}{l}>80 \\
>75 \\
>75\end{array}$ & $\begin{array}{l}>75 \\
>50 \\
>50\end{array}$ & $\begin{array}{l}<75 \\
<50 \\
<50\end{array}$ \\
\hline Pain & None & Occasional & Moderate & Severe \\
\hline Gait & Normal & Normal & Insignificant Limp & Significant Limp \\
\hline Strenuous Activities & Possible & Limited & Severed Limited & Impossible \\
\hline Table & uhs' Criteria for & aluation of & al Results & \\
\hline
\end{tabular}

\section{DISCUSSION}

The treatment of fractures had evolved over the years and attempts are made to improve the functional outcome with the minimum soft tissue trauma. The treatment of the complex metaphyseal fracture requires a thorough understanding of the fracture biology. The treatment method varies from conservative to internal fixation. 6,7

When open reduction and internal fixation is attempted with classical plates, it requires a quite larger incision causing extensive soft tissue dissection and periosteal injury and was associated with high rates of infection, delayed union and non-union. The scar tissue which developed was of a huge size. ${ }^{8}$

With the evolution of MIPO, several metaphyseal fractures are being treated with minimal surgery with precontoured locking compression plates, which has shown better wound healing, earlier callus formation allowing early union.

One grey area of confusion in comminuted fractures is whether primary bone grafting is indicated or not. Primary bone grafting is contraindicated if soft tissue dissection has to be done to place the graft. We have not done primary bone grafting in any of 37 cases. Bone grafting may be indicated if the healing is not progressive as assessed radiologically. Experimental works also reflect or explain the clinical results. Christian Krettek ${ }^{9}$ (1997) studied 12 human cadaver femurs with traditional plate osteosynthesis and minimally invasive plate osteosynthesis. The femurs with MIPO showed better periosteal and medullary perfusion with less disruption of perforators and nutrient arteries.

In our study, we found no relation of postoperative infection in cases which were earlier having a compound fracture. Out of the total 37 fractures 9 were having compound fracture, even then no one developed postoperative infection. So, we can conclude if proper aseptic precaution is taken. MIPO can be done even in some cases of compound fractures of lower extremity. The patient should be meticulously selected.

One of the disadvantages we faced while doing our study was the extensive use of the image intensifier. When compared to conventional plating where whole procedure is done under direct vision MIPO utilises a more time of image intensifier, because most of reduction is indirect and plate placement requires imaging.

The various advantages of MIPO are decreased soft tissue and periosteum damage, help maintain vascular supply to bone and soft tissue. Have better and faster callus formation, thereby better healing and union rate. There are decreased complications of infection and malunion and it also decreases or nullifies the use of supplementary bone grafting.

\section{CONCLUSION}

MIPO is an effective treatment in the treatment of metaphyseal fracture of long bone of lower limb. Technically, this procedure is demanding and needs expertise; requiring a cautious intraoperative clinical and fluoroscopic control in order to reestablish limb axis, rotation and length.

In our study, we are able to gain union in all fractures without the use of bone grafting and with minimal complications.

\section{REFERENCES}

[1] Wiss DA, Fleming CH, Matta JM, et al. Comminuted and rotationally unstable fractures of the femur treated with an interlocking nail. Clin Orthop Relat Res 1986;212:35-47.

[2] Baumgaertel F, Buhl M, Rahn BA. Fracture healing in biological plate osteosynthesis. Injury 1998;29(3):C36.

[3] Wenda K, Runkel M, Degreif J, et al. Minimally invasive plate fixation in femoral shaft fractures. Injury 1997;28( Suppl 1):A13-9.

[4] Johner R, Wruhs O. Classification of tibial shaft fractures and correlation with results after rigid internal fixation. Clic orth Relat Res 1983;178:7-25.

[5] Binkley JM, Stratford PW, Lott SA, et al. The lower extremity functional scale (LEFS): scale development, measurement properties, and clinical application. North American orthopaedic rehabilitation research network. Phys Ther 1999;79(4):371-83. 


\section{Jemds.com}

[6] Iannacone WM, Bennett FS, Delong WG, et al. Initial experience with the treatment of supracondylar femoral fractures using the supracondylar intramedullary nail: a preliminary report. J Orthop Trauma 1994;8(4):322-7.

[7] Henry SL. Supracondylar femur fractures treated percutaneously. Clin Orthop Relat Res 2000;375:51-9.

\section{Original Research Article}

[8] Greiwe RM, Archdeacon MT. Locking plate technology: current concepts. J Knee Surg 2007;20(1):50-5.

[9] Krettek C, Schandelmaier P, Miclau T, et al. Minimally invasive percutaneous plate osteosynthesis (MIPPO) using the DCS in proximal and distal femoral fractures. Injury 1997;28( Suppl 1):A20-30. 